\title{
Borut Pohar
}

\section{Transhumanizem v službi človekove odgovornosti do stvarstva}

\section{Transhumanism in the Service of Human's Responsi- bility for Creation}

Povzetek: Transhumanizem mnogi verniki zavračajo kot utopijo ali poskus zasesti mesto Boga. Vendar je že konec 19. stoletja pravoslavni teolog Nikolaj Fjodorovič Fjodorov gojil zamisel, da bi lahko človek s pomočjo znanosti postal uspešen sodelavec Boga pri odrešenju stvarstva. Njegova vizija transhumanizma oz. teologije, ki iz njega izhaja, je sicer skladna z vsemi viri katoliške teologije: Svetim pismom, tradicijo, razumom in verskim izkustvom. Tako Sveto pismo kot tudi sodobno cerkveno učiteljstvo namreč ljudem nalagata odgovornost do stvarstva, kar vključuje tudi njegovo obrambo pred uničenjem, hkrati pa je vizija človeka pri Fjodorovu v skladu z razumom in verskim izkustvom. Vendar je njegovo vizijo treba nujno prilagoditi katoliški zmerni srednji poti, ki se izogiba ekstremnim pozicijam in zagovarja previdnost. Vizija Fjodorova je koristna tako za kolektivni optimizem kot tudi za gojenje mednarodnega sodelovanja, ki je ena od glavnih poti k miru.

Ključne besede: transhumanizem, Nikolaj Fjodorovič Fjodorov, odrešenje, stvarstvo, glavni viri katoliške teologije

Abstract: Transhumanism is rejected by many believers as utopian or as an attempt to occupy the place of God. However, as early as at the end of the $19^{\text {th }}$ century, Orthodox theologian Nikolai Fyodorovich Fyodorov cultivated the idea that man could, through science, become collaborator of God in the salvation of the world. His vision of transhumanism or theology that comes from it, is consistent with all four main sources of Catholic theology: Scripture, tradition, reason in religious experience. Both the Bible and also modern Church teaching give humanity the task of responsibility for Creation, which also includes defense against it's destruction. Fyodorov's vision of man is also in accordance with reason and religious experience. However, his vision needs to be adapted to the Catholic Moderate Middle Way, which avoids extreme positions and advocates caution. Fyodorov's vision is also useful for both collective optimism and international collaboration, which is one of the main paths to peace.

Keywords: transhumanism, Nikolai Fyodorovich Fyodorov, salvation, Creation, main sources of catholic's theology 
Transhumanizem že kar nekaj časa buri duhove v javnih razpravah, še posebej, ko so vanje vključene tudi religije. Mnogi verniki ga zavračajo kot utopijo ali poskus zasesti mesto Boga. Vendar je že konec 19. stoletja pravoslavni teolog Nikolaj Fjodorovič Fjodorov gojil zamisel, da bi lahko človek s pomočjo znanosti postal uspešen sodelavec Boga pri odrešenju stvarstva. $V$ tej razpravi smo kot izhodišče vzeli njegovo idejo, da bo človek nekoč s pomočjo znanosti in tehnologije postal upravljavec vesolja, ki bo nadzoroval njegov razvoj, in preverjamo, ali je njegova vizija transhumanizma oz. iz njega izhajajoče teologije skladna z vsemi viri katoliške teologije: Svetim pismom, tradicijo, razumom in verskim izkustvom. Ugotavljamo, da tako Sveto pismo kakor tudi sodobno cerkveno učiteljstvo nalagata ljudem odgovornost do stvarstva, kar vključuje tudi njegovo obrambo pred uničenjem, hkrati pa je vizija človeka pri Fjodorovu v skladu z razumom in verskim izkustvom. Pri tem pa opozarjamo, da moramo njegovo vizijo prilagoditi katoliški zmerni srednji poti, ki se izogiba ekstremnim pozicijam in zagovarja previdnost. Vsekakor pa poskus takšne vizije pozdravljamo, saj je koristna tako za kolektivni optimizem kakor tudi za gojenje mednarodnega sodelovanja, ki je ena od glavnih poti k miru.

\section{Uvod}

Ena od definicij transhumanizma se glasi: "Transhumanizem je intelektualno in družbenopolitično gibanje, ki se ukvarja z mnoštvom vprašanj s področja bioetike, še posebej z vprašanji glede uporabe tehnologije za namen radikalne transformacije človeškega organizma. Glavni namen transhumanizma je spodbujanje uporabe biotransformativnih tehnologij, da bi izboljšali človeški organizem in ga s tem tako korenito spremenili, da bo presegel temeljne človeške omejitve in s tem človeka samega." (Porter 2017, 237-238)

Pri tem se nam zastavlja vprašanje, ali je transhumanizem s katoliškega vidika sprejemljiv ali predstavlja grožnjo njegovim temeljnim naukom? Ni malo takšnih, ki dvomijo, da ima lahko transhumanizem kakšen pozitiven doprinos k razvoju človeštva ali krščanstva. Politični filozof Francis Fukuyama (2004) je transhumanizem označil celo kot »najbolj nevarno idejo tega sveta«.

Nezaupanje pa goji tudi druga stran. Že od samega začetka je namreč sodobno angloameriško transhumanistično gibanje tradicionalno krščanstvo $v$ glavnem obravnavalo z velikim sumom in skepticizmom. Danes so mnogi izmed najbolj navdušenih transhumanistov prepričani ateisti, nekateri drugi pa prezirajo krščanske etične pomisleke npr. o raziskovanju matičnih celic. Vendar pa obstajajo tudi drugačni pogledi in pristopi. Rusko transhumanistično gibanje, ki je bilo ustanovljeno leta 2003, namreč v nasprotju z zahodnimi transhumanisti neskladja med krščanstvom in transhumanizmom ne vidi. To se med drugim kaže tudi v tem, da je za svojo inspiracijo vzelo delo predanega pravoslavnega kristjana Nikolaja Fjodoroviča Fjodorova (1829-1903), ki je svoje transhumanistične ideje o usodi človeštva črpal iz pravoslavne teologije, predvsem iz dela Maksima Spoznavalca (580662). Tu lahko torej vidimo, da transhumanizem in krščanstvo nista nujno nezdru- 
žljiva. Za Maksima in Fjodorova je človek svobodno bitje, ki ga je Bog pri odrešenju stvarstva izbral za sodelavca. Končni cilj odrešenja je po njunem prepričanju poboženje (gr. theosis) stvarstva, kar pomeni njegovo radikalno transfiguracijo (Clay 2005, 157-158). Ker je Fjodorov Maksimovo idejo o človekovem sodelovanju pri kozmični odkupitvi jemal resno, je trdil, da bi se moralo vse človeštvo združiti in poskusiti uresničiti skupen transhumanistični cilj, ki je sestavljen iz treh nalog: (1) povrnitev sveta v blaženo stanje neminljivosti, (2) obujanje mrtvih in (3) postati upravitelj vesolja (158). V tej njegovi zamisli lahko zaslutimo prisotnost krščanske ideje o odgovornost ljudi do živih in mrtvih ter do stvarstva na splošno, ki jo ima Fjodorov za glavno motivacijo svojega transhumanističnega projekta. Transhumanizma ne vidi v službi političnih ciljev in človeških teženj po oblasti, moči in slavi, temveč v službi uresničevanja človekove odgovornosti do ljudi in do celotnega stvarstva, ki mu jo je naložil Bog. $V$ tej razpravi se osredotočamo samo na eno od transhumanističnih idej Fjodorova - da bo človek v prihodnosti s pomočjo znanosti in tehnologije postal upravljavec vesolja.

Vizija teološkega transhumanizma pri Fjodorovu je pomembna z dveh vidikov. Kot prvo, napoved prihodnosti vesolja je temačna, saj ga po vseh možnih scenariji čaka takšna ali drugačna smrt oz. uničenje. Pri tem se moramo nujno vprašati, ali nam ni morda Bog res dal poslanstva, da pomagamo to katastrofo preprečiti? Ali se zdi ta ideja preveč nora in utopična? Drugi problem, ki ga Fjodorov omenja implicitno, so tisočletja mednarodnih konfliktov, ki jim ni in ni videti konca. Fjodorov je prepričan, da bi bil skupen projekt reševanja stvarstva dobra priložnost za graditev sodelovanja med narodi, kar je nujen predpogoj za širitev miru.

$\checkmark$ nadaljevanju bomo pokazali, da je vizija transhumanizma pri Fjodorovu do določene mere skladna z glavnimi viri katoliške teologije, namreč s Svetim pismom, cerkvenim učiteljstvom, razumom in verskim izkustvom (prim. McGrath 2014, 191). Kot njeno glavno pomanjkljivost pa bomo izpostavili pretiran optimizem in predlagali, da jo postavimo v okvir tradicije katoliškega zmernega optimizma, ki se izogiba ekstremnim pozicijam in išče srednjo pot.

Dolžnost odgovornega upravljanja s stvarstvom je eden od ključnih elementov cerkvenega družbenega nauka. Ta ideja je prisotna tako v Svetem pismu kakor tudi v sodobnem cerkvenem učiteljstvu.

\section{Sveto pismo priča o človekovi odgovornosti do stvarstva}

Sveto pismo na več mestih jasno pravi, da je Bog ljudem zaupal stvarstvo v skrb, zato morajo z njim ravnati odgovorno. $V$ poročilu o stvarjenju tako zasledimo naslednje besede: „Naredimo človeka po svoji podobi, kot svojo podobnost! Gospoduje naj ribam morja in pticam neba, živini in vsej zemlji ter vsej laznini, ki se plazi po zemlji!« (1 Mz 1,26). Tudi v drugih delih Svetega pisma najdemo misel o pravici gospodovanja človeka nad stvarstvom (prim. Ps 8; Ps 19,1-6). Vendar nas Sveto 
pismo opozarja, da to gospodovanje ni samovoljno, ampak mora biti do svojega Stvarnika odgovorno. Prerok poroča: "Gospod Bog je vzel človeka in ga postavil v edenski vrt, da bi ga obdeloval in varoval« $(1 \mathrm{Mz} 2,15)$. Zanimiva sta oba glavna poudarka tega stavka, namreč, da je naloga človeka, da edenski vrt obdeluje in varuje. Tudi na svetu, ki ni bil zaznamovan s posledicami izvirnega greha, je bila naloga človeka tako delo kot varovanje, kar je nekoliko v nasprotju s pričakovanji. Zakaj bi bilo namreč v popolnem svetu brez greha sploh treba delati in varovati vrt? Kakorkoli, Adam je dobil nalogo, da svoj novi dom nadzoruje in skrbi za to, da ostaja Gospodov vrt, kar pomeni, da odganja sovražnike (kačo) in skrbi, da bodo žena in bodoči otroci svojega Stvarnika ubogali. Človek ima torej že od samega začetka odgovornost, in sicer da soustvarja skupaj s Stvarnikom in mu pomaga pri obrambi tega, kar skupaj ustvarjata. Gre za podobno razmerje kot starši : otroci, ko začnejo starši delo postopoma prepuščati otrokom in jim ga na koncu tudi prepustijo. Vendar pa sta se Adam in Eva tej odgovornosti izneverila. Pustila sta, da je v vrt vdrl sovražnik; nista ga izgnala, temveč sta mu podlegla. Človekova neodgovornost je torej omogočila, da je v svet vdrl greh, $s$ katerim je človek postal ranjen; preprečena mu je bila pot do brezgrešnega življenja in posedovanja resnice.

Druga zgodba iz Prve Mojzesove knjige, ki govori o človekovi odgovornosti do stvarstva, je Noetova zgodba (prim. $1 \mathrm{Mz} 6,5-9,17$ ). Bog je zaradi greha ljudi sklenil svet uničiti. Vendar ne vsega, kar je na njem. Prerok poroča: »Noe pa je našel milost v Gospodovih očeh « (1 Mz 6,8). Ker je svetu grozilo popolno uničenje, je Bog dal Noetu nalogo, da živa bitja pred njim obvaruje. Naročil mu je: »Pojdi torej $v$ ladjo ti in s teboj tvoji sinovi, tvoja žena in žene tvojih sinov! In od vseh živali, od vsega mesa, spravi po dvoje v ladjo, da bodo skupaj s teboj ostale pri življenju!« (1 Mz 6,18-19). Bog bi lahko sam živa bitja ponovno ustvaril iz nič in tako stvarstvo obnovil. Vendar se je odločil, da bo v reševanje življenja na svetu vključil tudi Noeta, in sicer konkretno tako, da mu je živa bitja pomagal rešiti.

Svetu vedno znova grozijo katastrofe. Ne moremo sicer vedeti, ali je njihov vzrok greh ljudi ali ne. Jezus nas je opozoril, da ne smemo delati prehitrih zaključkov. Pokaral je na primer ljudi, ki so za vsako trpljenje človeka videli kot vzrok greh njega samega ali njegovih staršev: »Ali pa onih osemnajst, na katere se je podrl stolp v Síloi in jih ubil, mar mislite, da so bili večji dolžniki kakor vsi drugi prebivalci Jeruzalema?« $($ Lk 13,4). Ne glede na to, kaj je vzrok katastrofe, imamo ljudje odgovornost, da pomagamo svet reševati.

Tudi iz Jezusovih besed je mogoče razbrati, da smo dolžni za stvarstvo skrbeti. Jezus je nenehno opozarjal na posledice človekove navezanosti na bogastvo ali moč. Nagibi, ki na stotine milijonov ljudi tretjega sveta pehajo v revščino in hkrati uničujejo naš planet, pogosto izhajajo iz pohlepa. Jezus pravi: »Kako težko bodo tisti, ki imajo premoženje, prišli v Božje kraljestvo!» (Mr 10,23; Lk 16,19-31). Življenjska drža, ki izhaja iz evangelija, omogoča obvarovanje pred nasiljem ne le ljudem, ampak varuje pred uničenjem tudi stvarstvo.

Če se Sveto pismo začenja z opisom stvarjenja neba in zemlje, ki ju Bog zaupa človeku $v$ varstvo in skrb, se $v$ Knjigi razodetja končuje $z$ njunim odrešenjem 
(Raz 21,1-22,5). Krščanski nauk zagovarja misel, da smo ljudje enota telesa, duše in duha, in da bo skupaj z dušo in duhom poveličano tudi telo. O tem nam lepo priča dogodek Jezusovega prikazanja učencem po vstajenju od mrtvih (Lk 24,3649). Ker niso verjeli, da je to res on, jim je rekel: "Poglejte moje roke in moje noge, da sem jaz sam. Potipljite me in poglejte, kajti duh nima mesa in kosti, kakor vidite, da jih imam jaz« (Lk 24,39). In ker kljub temu niso verjeli, je šel še korak dlje in je vpričo njih pojedel kos pečene ribe. Ta odlomek govori o tem, da v nebesih ne bomo prisotni samo v obliki duše in duha, ampak bomo imeli tudi svoje snovno telo, za katerega pa bodo veljale drugačne zakonitosti kot sedaj na zemlji. Apostol Janez tako pričuje: "Nato sem videl novo nebo in novo zemljo« (Raz 21,1). To pa ne velja samo za naša telesa, ampak tudi za stvarstvo kot takšno. Knjiga razodetja nam podaja vizijo novega neba in nove zemlje.

Pri tem se nam takoj zastavi vprašanje: Kakšna je vloga človeka pri tem odrešenju? V kolikšnem deležu lahko kot človeštvo k odrešenju prispevamo (sami)? Vsekakor se teologija o tem premalo sprašuje, saj odrešenje sveta postavlja skoraj izključno v domeno Jezusovega drugega prihoda in njegove zmage nad zlom.

\section{Sodobno cerkveno učiteljstvo pritrjuje Svetemu pismu}

Zadnjih nekaj deset let, ko se vedno več govori o prihodnji ekološki katastrofi, je cerkveno učiteljstvo glede človekovega odnosa do stvarstva podalo več izjav.

Papež Pavel VI. je v okrožnici Populorum Progressio leta 1967 zapisal, da je bilo stvarstvo ustvarjeno zaradi človeka in zanj z namenom, da ga odgovorno razvija naprej: "Sveto pismo nas od prve strani naprej uči, da je Bog celotno stvarstvo ustvaril za človeštvo in da je odgovornost vseh nas, da ga, v naše dobro, razvijamo in izpopolnjujemo s pomočjo našega razuma in fizičnega dela« (PP, tč. 22).

K odgovornosti do stvarstva poziva tudi Kompendij družbenega nauka Cerkve:

॥Skrb za okolje predstavlja izziv za vse človeštvo. Naša skupna in univerzalna dolžnost je, da spoštujemo skupno dobro, ki je namenjeno vsem nam. To dolžnost izvršujemo tako, da preprečujemo, da bi kdorkoli brez kazni enostavno po svoji volji uporabljal bitja vseh vrst, tako živa kot neživa - živali, rastline in naravne elemente - in sicer za svoje ekonomske potrebe. $V$ tem primeru gre za odgovornost, ki mora zoreti na podlagi globalne razsežnosti sedanje ekološke krize, pri čemer je nujno, da jo prebujamo po vsem svetu, kajti v vesoljnem redu, ki ga je postavil Stvarnik, so vsa bitja med seboj tesno povezana.« (2005, tč. 466)

Enakega mnenja so tudi ameriški katoliški škofje, ki so v svoji izjavi zapisali: »Temeljna vez med človeštvom in naravo je človekova skrb za stvarstvo« (Renewing the Earth 1991, tč. 2).

Pri tem ima pomembno vlogo predvsem država. Papež Janez Pavel II. je dejal, da ima država nalogo, da »zagotavlja obrambo in ohranjanje skupnega dobrega, 
kakor je naravno ali človeško okolje, ki jih ne moremo zaščiti le z silami trga« (CA, tč. 40). Papež Benedikt XVI. je dodal, da ta odgovornost pritiče tudi Cerkvi: "Cerkev ima do stvarstva odgovornost, ki jo mora uveljavljati na javnem področju« (CV, tč. 51.).

Kaj naj bi bila motivacija za takšno odgovornost? Cerkveno učiteljstvo poudarja, da mora biti motivacija zavest, da smo pri stvarjenju sveta Božji sodelavci. Janez Pavel II. je v tem duhu zapisal: „Najgloblji motiv za naše delo je zavest o tem, da imamo delež v stvarstvu« (LE, tč. 25). Podobno trdijo tudi ameriški katoliški škofje: "Moramo biti pristni oskrbniki narave in torej sostvaritelji novega človeškega sveta. To pa od nas zahteva, da vzpostavimo nove odnose in se lotimo novih dejanj« (Renewing the Earth 1991, tč. 5). Ameriški katoliški škofje so v mednarodnem pastoralnem pismu $(2001$, tč. 9) k temu dodali tudi misel, da smo ljudje pri soustvarjanju sveta udeleženi tudi pri Božji ustvarjalnosti:

»Bog, ki ima edini moč stvarjenja, nas vabi, da sodelujemo pri tem ustvarjanju. Ljudje imamo torej edinstveno vlogo. $V$ fizičnem vesolju imamo edino ljudje možnost, da zavestno skrbimo za stvarstvo /.../ Ustvarjeni smo po Božji podobi in sličnosti in imamo poslanstvo, da smo oskrbniki Božjega ustvarjenega in čudovitega vesolja."

$\mathrm{K}$ čemu nas zavezuje odgovornost, ki jo imamo do stvarstva? Papež Frančišek (2013) trdi, da je ena od nalog vsakega človeka tudi varovanje stvarstva: „Cerkev se zaveda odgovornosti, ki jo ima vsak od nas do tega sveta in do vsega stvarstva, ki ga moramo ljubiti in ščititi." Enako trdijo ameriški katoliški škofje: »Naša tradicija nas poziva, da zaščitimo življenje in dostojanstvo človekove osebe, pri čemer vedno bolj postaja jasno, da te naloge ne moremo ločiti od skrbi in obrambe celotnega stvarstva« (1991, št. 2). Po njihovem prepričanju je torej ljubezen do sočloveka neizogibno povezana z ljubeznijo do stvarstva, ki vključuje tudi njegovo zaščito. Enakega mnenja je tudi zaslužni papež Benedikt XVI.: »lzkušnja nam pravi, da zanemarjanje okolja vedno škodi človekovemu sobivanju, pri čemer velja tudi obratno. Vedno bolj in bolj postaja očitno, da med mirom s stvarstvom in mirom med ljudmi obstaja neločljiva vez« (2007, tč. 8). In dalje: "S tem, da človek pokaže svoj čut za odgovornost do stvarstva, pokaže tudi to, da spoštuje samega sebe /.../ Ne smemo pozabiti, da je boj za dostop do naravnih virov eden od vzrokov za številne konflikte v Afriki, drugod po svetu pa nenehna grožnja za njihov nastanek. Zaradi tega vedno znova ponavljam, da je zaščita okolja predpogoj za gojenje miru.« (2010)

Ameriški katoliški škofje (15. junij 2001) poudarjajo, da naša dolžnost ščitenja stvarstva izhaja iz dejstva, da smo oskrbniki Božjega stvarstva, in tega, da imajo naša dejanja posledice za naše potomstvo:

"V svojem bistvu svetovne podnebne spremembe ne zadevajo ekonomskih teorij ali političnih razprav, niti napredka ali pritiska interesnih skupin. Zadevajo prihodnost Božjega stvarstva in ene človeške družine. Zadevajo našo dolžnost, da zaščitimo tako človeško kakor tudi naravno okolje, zadevajo 
pa tudi našo vlogo, da smo oskrbniki Božjega stvarstva in našo odgovornost do teh, ki bodo prišli za nami.«

Vsi ti različni dokumenti, ki jih je cerkveno učiteljstvo izdalo v sodobnem času - in bi jim lahko pridružili še številne druge dokumente -, torej pričajo, da človekova odgovornost do stvarstva izhaja iz dejstva, da ga je Bog postavil za oskrbnika oz. soustvarjalca, pa tudi iz tega, da imajo naša dejanja posledice za prihodnje rodove. Eden od njihovih sklepov je tudi ta, da odgovornost do stvarstva vključuje dolžnost, da ga ščitimo pred uničenjem. To pa je popolnoma v skladu z vizijo človeka kot upravitelja vesolja pri Fjodorovu.

\section{Ali je vizija človeka pri Fjodorovu sploh razumna?}

Razum je bil znotraj katoliške tradicije ves čas cenjen, saj je teologijo vedno imela za racionalno disciplino. To stališče je še posebej zagovarjal Tomaž Akvinski. Da je vera racionalna, pomeni, »da je razum zmožen podpreti ideje vere« (McGrath 2014, 226). Najbolj očiten primer je iskanje razumskih razlogov za vero v Boga, ki jih je Tomaž predstavil v svojih petih poteh. Pri tem se moramo seveda zavedati, da "vera presega razum, saj ima dostop do resnic in uvidov razodetja, o katerih razum ne more upati, da bi jih lahko dognal ali odkril brez pomoči« (226). Na podlagi filozofije religije lahko rečemo, da je krščanska vera v resonanci z dognanji razuma. Dokazi za obstoj Boga tega sicer ne dokazujejo, ampak sporočajo le to, da je vera skladna $z$ razumom.

Kaj pomeni, da je nekaj razumno? V prvi vrsti to, da je v skladu z razumskimi predpostavkami. Med njimi je tudi princip zadostnega razloga, ki pravi, da mora biti vsako naše prepričanje podprto z razlogi. Sicer pa razumske predpostavke niso univerzalne. Predpostavke nam vzbujajo pričakovanja o tem, kako se bo vedel svet okoli nas. Vsekakor je danes (bolj ali manj sprejeto) dejstvo, da kanon predpostavk o tem, kaj je razumno, v veliki meri kreira sodobna znanost. Če je nekaj v nasprotju s tem, kar trdijo ali odkrijejo znanstveniki, potem to v (strokovni) javnosti ne velja za razumno oz. sprejemljivo, saj ni v skladu s pričakovanji.

Torej se lahko vprašamo tudi, ali so ideje, ki so rezultat razmišljanj Nikolaja Fjodoroviča Fjodorova, z današnjega pojmovanja racionalnosti sploh razumne ali gre morda za pretiravanja, ki mejijo celo na patološkost? Oglejmo si še enkrat njegove tri velike naloge, ki naj bi jih Bog zaupal človeštvu: (1) ponovna povrnitev sveta v blaženo stanje neminljivosti, (2) obujanje mrtvih in (3) postati upravitelj vesolja. Za prvi dve nalogi bi težko rekli, da sta z današnjega vidika razumni, saj zanju nimamo niti teološke niti znanstvene podlage, ki bi vsaj nakazovala, kako bi se ju dejansko dalo izvesti. Še več, za to imamo celo protiargumente. Stvarstvo se nam npr. kaže kot prigodno, vse, kar je živega, pa kot umrljivo oz. minljivo in hkrati tudi zaznamovano z velikim trpljenjem. Nič v znanosti nam ne daje slutiti, da bi lahko upali, da bomo nekoč prigodnost, ki je podvrženo vse, premagali in obujali mrtve. Tudi teološko bi bil takšen podvig sporen, saj sta po tradicionalni teologiji 
oz. filozofiji ravno prigodnost oz. nenujnost celotnega stvarstva ter umrljivost vsega živega tista, ki ločita stvarstvo od svojega Stvarnika. Če bi človek z napredkom znanosti in tehnologije dobil sposobnost vzpostavljanja neminljivosti in nujnosti vesolja ter sposobnost obujanja mrtvih - potem sploh ne bi bil več človek, ampak Bog, kar pa je teološko popolnoma nezamisljivo. V Svetem pismu sicer imamo primere, ko je prerok obudil koga od mrtvih, vendar je to storil v moči Boga in ne samostojno s pomočjo napredne znanosti in tehnologije. Vsekakor sta v luči sodobne znanosti in teologije prvi dve nalogi - vsaj zaenkrat - videti nedosegljivi in bi ju bilo torej nerazumno zagovarjati.

Po našem mnenju pa to ne velja za tretje človekovo poslanstvo, namreč da postane upravitelj vesolja. Teološko $v$ tem ni nič spornega, kar smo ravnokar pokazali z navajanjem Svetega pisma in izjav cerkvenega učiteljstva, ki človeku dolžnost odgovornega ravnanja z Božjim stvarstvom, kar vključuje tudi obrambo pred uničenjem, celo nalagajo. Seveda je vprašanje, do katere mere človek upravljavec vesolja lahko sploh postane, saj kot pravi Jezus: „Učenec ni nad učiteljem in služabnik ne nad svojim gospodarjem « (Mt 10,24). Res pa je tudi, da je Jezus rekel: »Resnično, resnično, povem vam: Kdor veruje vame, bo dela, ki jih jaz opravljam, tudi sam opravljal, in še večja kot ta bo opravljal, ker grem jaz k Očetu« (Jn 14,12). Ta izjava je za Fjodorova pri upravičevanju njegovih idej ključna . Toda - kot prvo, Jezus nikakor ni rekel, da bo človek lahko delal vse, kar bo hotel. Vprašanje je, ali je Jezus s tem mislil na tako radikalne ideje, kot je človekova ukinitev naravnih zakonov - na primer darvinističnega boja za preživetje ali drugega zakona termodinamike. Človek nikoli ne bo postal Bog, ampak bo vedno ostal njegov učenec in služabnik. Nekatere stvari so pridržane za Boga. Kot drugo - pozorni moramo biti, da Jezus kot pogoj opravljanja velikih del zahteva vero, čeprav res ne prav veliko. Učencem je dejal: „Če bi imeli vero kakor gorčično zrno, bi rekli tej murvi: ১lzruj se s koreninami vred in se presadi v morje, ( in bi vam bila pokorna « $($ Lk 17,6$)$. Jezus ni rekel, da je za izruvanje murve potrebno kakšno posebno znanje ali tehnologija - že vera vanj naj bi zadoščala. Zato tudi veliko znanja in najboljša tehnologija brez vere nikoli ne bosta mogla opraviti večjih del, kot jih je storil on sam.

To pa ne pomeni, da ideja o človeštvu kot upravitelju vesolja sama po sebi ni razumna, seveda če jo vzamemo v manj radikalni obliki. Ljudje smo v kratkem času $v$ marsičem postali upravitelji stvarstva, pri čemer nas to seveda še vedno ogroža. Glede na današnje stanje znanosti bi bila lahko na primer čisto sprejemljiva naslednja misel Fjodorova: "S svojim razumom bodo človeški sinovi usmerili slepo gibanje planetov in celotnih sončnih sistemov« (Fjodorov 1995-2000). Za ta optimizem podajamo naslednja dva razloga:

Kot prvo, človeštvo je $v$ zelo kratkem času $v$ znanosti in tehnologiji izjemno napredovalo. Kar je bilo včasih za ljudi nemogoče, je postala vsakodnevna stvarnost. Ameriški znanstvenik in izumitelj Benjamin Franklin (1706-1790) je napovedal hitrost napredka z naslednjimi besedami: "Glede na to, s kolikimi akademijami znanosti je sedaj posejana Evropa, z vsemi inštrumenti in duhom preizkusa, ki jih te akademije imajo, bo napredek človeškega znanja zagotovo hiter in sledila bodo velika odkritja, o katerih se nam danes niti ne sanja. Postaja mi skorajda žal, da 
sem se rodil tako kmalu, saj nimam te sreče, da bi vedel, kar bodo ljudje vedeli čez sto let « (Founders Online, 2019). Več kot očitno je, da se je njegova napoved uresničila. Jerry A. Coyne, velik navdušenec nad znanostjo in velik nasprotnik religije - v slovenščino imamo prevedeno njegovo knjigo Faith vs. Fact (Verjeti ali vedeti) -, se čudi, kaj vse je znanost odkrila za časa njegovega življenja: „V svojem življenju sem dočakal iztrebljenje črnih koz in otroške paralize, odkritje velikega poka, razvozlanje strukture DNK, sposobnost transplantacije organov, rekonstrukcijo velike dela evolucijske zgodovine življenja, osebne računalnike, pristanek človeka na Luni, potovanje z vesoljskim čolničkom, raziskovanje površine Marsa z robotskim vozilom, oploditev v epruveti, mobilno telefonijo, cepivo proti virusu HIV in identificiranje Higgsovega bozona - in to so samo stvari, ki so se zgodile po letu 1949« (Coyne 2018, 131). Glede na tako bliskovit napredek si res težko predstavljamo, kakšno bo stanje znanosti čez več $10^{\text {n }}$ let, če se je že v tako kratkem času zgodilo toliko. In koliko časa imamo?

Dejansko zelo veliko - v kozmološkem merilu je kratek čas napredka od začetka moderne dobe pa do danes zanemarljivo majhen, poleg tega je pred nami neznanska količina časa za nadaljnji razvoj. Mnogo ljudi si je v zgodovini že zastavilo vprašanje: Zakaj ni Bog Jezusa poslal na zemljo že prej? Zakaj šele tako pozno? Z vidika človeškega življenja se mogoče 13,7 milijarde let, kolikor je minilo od velikega poka, ter 300.000 let, ki so minila od nastanka modernega človeka (Homo Sapiens), zdi veliko. A vesolje je praktično šele v povojih in do njegovega konca je še zelo daleč. O usodi vesolja obstajajo različne teorije, vendar nobena ne napoveduje nič dobrega. Obstajajo trije glavni možni scenariji, pri čemer ključno vlogo igra t. i. temna snov. Prvi scenarij pravi, da se bo vesolje širilo vedno počasneje, vse dokler se ne bo ustavilo, čemur bo sledilo krčenje in ponovna zgostitev v eni neskončno majhni točki izjemne gostote. Potem bo nastal nov veliki pok. Po drugem scenariju se bo vesolje širilo v neskončnost in se pri tem ohlajalo, zaradi česar ga bo doletela toplotna smrt. Vesolje se bo namreč tako ohladilo, da bo vse obstalo. Za zdaj meritve kažejo, da je ta scenarij najbolj verjeten. Zadnji scenarij, ki ga podpirajo nedavna opazovanja, da se vesolje pospešeno širi, pa napoveduje, da bo vedno večja količina temne snovi, ki nastaja s prostorom, na koncu vesolje raztrgala oz. uničila. Vsi trije scenariji konec vesolja postavljajo v desetine, stotine ali celo tisočine milijard let, kar je za človeške razmere nepredstavljivo veliko časa (Glanz 2009).

Glede na osupljiv napredek znanosti in tehnologije v zadnjih desetletjih in neznansko količino časa, ki ga ima vesolje še pred seboj, je razumljivo sklepati, da bo človeštvo v bližnji in daljni prihodnosti zaradi hitrega razvoja znanosti in tehnologije lahko imelo na vesolje zelo velik vpliv, zaradi česar bo vedno lažje branilo stvarstvo pred uničenjem. S tehnologijo, ki jo imamo danes, bi morda že lahko celo obvarovali naš planet pred katastrofo, ki bi jo povzročil padec velikega meteorita na zemljo. To, kar je bila včasih znanstvena fantastika, je danes v marsikaterem primeru že realnost. Ideja Fjodorova o vlogi človeštva kot upravitelja vesolja se torej zdi precej realna, čeprav ne vemo, kje so meje znanstvenega in tehnološkega napredka. Ali bo človeštvo nekoč imelo na voljo znanje in tehnologijo, da bi 
lahko preprečilo smrt vesolja? Glede na to, da potencialno lahko že danes preprečimo uničenje našega planeta $z$ asteroidom, zakaj bi torej vprašanje, nanašajoče se na čas, ki je neznansko oddaljen od današnjega, imeli za nerazumno ali morda celo nesmiselno?

\section{Ali je transhumanizem Fjodorova v skladu z verskim izkustvom?}

Vsekakor mora biti transhumanistična teologija, ki govori o človekovi vlogi kot o soodrešitelju sveta, skladna z verskim izkustvom. Navajamo dvoje v fenomenologiji dobro poznanih verskih izkustev, ki sta v skladu s teološko idejo Fjodorova, da je človek v Božjem načrtu upravljavec vesolja. To sta izkustvo zavedanja lastnega obstoja in izkustvo odrešene eksistence.

Eksistencialisti pravijo, da je ena od najpomembnejših stvari, ki človeška bitja loči od drugih živih bitij, to, da se zavedamo svojega lastnega obstoja in se o njem celo sprašujemo. Tega izkustva živali nimajo. Eksistencialna filozofija tako podaja odgovor na vprašanje, kaj pomeni obstajati.

Kot prvo, obstajati za človeka pomeni zavedati se svojega obstoja. Eksistencialisti so ugotovili naslednje: "Ne le, da obstajamo, razumemo, zavedamo se, da obstajamo, zavedamo pa se tudi, da bo naš obstoj nekega dne končala smrt. Golo dejstvo našega obstoja je za nas pomembno; težko, morda celo nemogoče je, da bi do njega privzeli povsem nepristranski odnos" (McGrath 2014, 235). Ne le, da se zavedamo obstoja, zavedamo se tudi minljivosti (obstoja) prihodnjih rodov in minljivosti vesolja kot takšnega, do česar smo ljudje prišli z znanstvenim raziskovanjem. Brez zavedanja nenehne grožnje smrti človek ne bi imel pravega motiva za izpopolnjevanje načinov, kako ji ubežati. Grožnja minljivosti in smrti je eno od gonil napredka. Versko izkustvo zavedanja lastne minljivosti lahko osmislimo - in se torej sklada - s teološko razlago, da je ena od nalog človeka, da brani sebe, druga bitja in vesolje pred uničenjem oz. smrtjo. Če tega izkustva ne bi bilo, potem si ne moremo predstavljati, da bi Bog človeku to nalogo dal, saj je ne bi mogel izpolniti. Vizija človeka kot upravljavca vesolja pri Fjodorovu je torej v skladu s človekovim izkustvom lastne minljivosti, ki nas žene v odkrivanje načinov, kako se je rešiti.

Kot drugo, za človeka obstajati pomeni izkušati svojo eksistenco kot odrešeno ali kot neodrešeno. Po Rudolfu Bultmannu Nova zaveza loči med neverujočo, neodrešeno eksistenco, ko človek ne priznava odvisnosti od Boga in misli, da je samozadosten, in verujočo, odrešeno eksistenco, ko se človek odreče varnosti, ki bi si jo ustvaril sam, in zaupa v Boga ter njegovo milost. Čeprav je cilj prizadevanj neodrešene eksistence dober, pa je sredstvo, torej zanašanje samo na lastne moči, neprimerno in zato vodi v vedno večjo ujetost v svet smrti in obupa. Znanstveniki ob raziskovanju sveta odkrivajo vseprisotno prigodnost stvarstva, ki ji ni videti konca kljub nenehnem znanstvenem napredku. Ne poznati konca oz. dna pa dejansko pomeni neobvladovanje stvarstva. Če skrivnostim narave ne moremo priti 
do dna, je tudi ne moremo obvladovati, saj je cilj raziskovanja tudi obvladovanje. Brez teorije vsega smo nemočni. In nemoč vodi v obup. Če bi človek svojo eksistenco lahko izkušal samo kot neodrešeno, potem bi bila ideja človeka kot odgovornega upravljavca vesolja nesmiselna, saj bi bila že vnaprej propadel projekt, brez upanja na končni uspeh. Vendar lahko človek svojo eksistenco izkuša tudi kot odrešeno, to je utemeljeno na Božji milosti. Čeprav odrešeni človek še naprej živi v svetu, ni več od tega sveta (Jn 17,15-16; McGrath 2003, 188). Obstoj izkustva odrešene eksistence je v skladu s teološko idejo človeka kot odgovornega upravljavca Božjega stvarstva, saj si je težko predstavljati, da bi Bog takšno nalogo zaupal nekomu, ki se je sposoben zanašati samo na svoje moči in tako neprestano živi v dvomu in strahu. Bilo bi nesmiselno, da bi Bog zaupal to veliko, pomembno in odgovorno nalogo nekomu, ki ni človek upanja, saj svoje gotovosti ni zmožen utemeljiti na nečem, kar ni prigodno, minljivo, smrtno. Človek je lahko odgovoren upravljavec vesolja le, če zaupa v Božjo milost in v končno zmago dobrega. Transhumanizem Fjodorova je torej skladen tudi z verskim izkustvom odrešene eksistence, saj je to izkustvo v njegovi luči pričakovano.

Vidimo torej, da sta obe pomembni fenomenološki izkustvi, tako izkustvo lastne minljivosti kakor tudi izkustvo odrešene eksistence, v skladu z idejo človeka kot odgovornega upravljavca vesolja pri Fjodorovu, saj sta z njenega vidika pričakovana. S tem, ko sta pričakovana, pa sta za katoliško teologijo tudi sprejemljiva.

\section{Sklep}

Na podlagi analize skladnosti tranhumanistične teologije pri Fjodorovu lahko trdimo, da je ta vsaj v tretji točki skladna z vsemi temeljnimi viri katoliške teologije. Vendar to ne pomeni, da je za katoliško občinstvo avtomatsko sprejemljiva. Narediti je treba zadnji korak, to je postaviti jo v okvir katoliške zmerne srednje poti.

Ena od temeljnih lastnosti krščanstva je njegova sposobnost, da zna udomačiti tuje filozofije, nauke in prakse, ki na prvi pogled z njim nimajo nič. O tem, kako se kristjanom ni treba bati ničesar, pričajo Jezusove besede, s katerimi je svojim učencem obljubljal imunost na vsakršno zlo: „Tiste pa, ki bodo sprejeli vero, bodo spremljala ta znamenja: $v$ mojem imenu bodo izganjali demone, govorili nove jezike, z rokami dvigali kače, in če bodo kaj strupenega izpili, jim ne bo škodovalo« (Mr 16,17-18). Če Jezusovemu učencu ne morejo škodovati niti kače niti strupi, zakaj bi mu škodoval nauk, kot je transhumanizem Fjodorova? Ni razloga, da ne bi katoliška teologija posvojila tudi tega, seveda pod pogojem, da ga prej prilagodi svojim standardom. Najprej ga mora spremeniti v zmernejšo obliko.

Eden od elementov transhumanizma Fjodorova, ki je za katoliško teologijo nesprejemljiv, je idealizirana podoba človeka oz. pretiran optimizem glede človekovih zmožnosti. To je tudi njegov skupni imenovalec s komunizmom, ki je gojil - oz. ponekod po svetu še vedno goji - naivno idejo, da smo ljudje zmožni ustvariti popolno družbo brez nasilja in s popolnimi medsebojnimi odnosi, ki temeljijo na 
nesebični solidarnosti, enakovrednosti in medsebojnem sodelovanju. Seveda za nastanek takšne popolne družbe potrebujemo popolnega človeka, ki je zmožen takšne popolne odnose ustvariti. Vendar se je v 20. stoletju ta idealizem v praksi izkazal za utopičnega, še več, za zelo nevarnega, saj je pahnil v smrt na milijone nedolžnih ljudi. Izkazalo se je, da je krščanski nauk o izvirnem grehu, to je nauk o človekovi ranjenosti oz. nepopolnosti, še kako resničen. Ta nauk nas uči, da popolna družba ni mogoča, ker človek ni moralno popolno bitje. Na sploh si katoliška teologija vedno prizadeva brzdati ekstreme in ubira zmerno srednjo pot med njimi. Kot je dejal pisatelj in teolog C. S. Lewis: „Ljudje, ki imajo preveč optimističen pogled na ta svet, bodo slej ko prej postali pesimisti; ljudje, ki so do sveta vedno do neke mere zadržani oz. kritični, imajo pogoje, da sčasoma postanejo optimisti « $(1970,52)$. Da je to res, nam je pokazala zgodovina sama.

Vendar pa krščanski nauk o izvirnem grehu ne svari samo pred utopično idejo moralno popolne družbe, ampak tudi pred utopično idejo, da bomo nekoč imeli $v$ posesti vso resnico o sebi in tem svetu. Posledice izvirnega greha namreč niso prizadele zgolj moralne dimenzije človeka, ampak tudi noetične. Vendar se katoliški nauk tudi v tem primeru ekstremnim stališčem izogne. Katekizem katoliške Cerkve v nasprotju z nekaterimi protestantskimi nauki pravi, da »človeška narava ni povsem pokvarjena: ranjena je v svojih lastnih naravnih močeh; podvržena nevednosti, trpljenju in gospostvu smrti; in nagnjena h grehu « (tč. 405). Nevednost pomeni nepopolno posedovanje resnice. Janez Pavel II. je v tem duhu v svoji okrožnici Vera in razum opozoril, da nam resnica ni dana neposredno, ampak preko njenih izrazov, ki »nosijo pečat zgodovine in so, še več, delo človeškega razuma, katerega je ranil in oslabil greh« (FR, tč. 51). Ne samo torej, da je vse naše védenje zgodovinsko in kulturno pogojeno, ampak je nepopolno tudi zato, ker ima razum zaradi svoje ranjenosti svoje omejitve.

Katoliški nauk nas torej opozarja, naj bomo v vsem zmerni optimisti, ne samo v zadevah morale narave, ampak tudi v noetičnih sposobnostih našega razuma, da doseže resnico. $V$ tem duhu lahko tudi vizijo Nikolaja Fjodoroviča Fjodorova označimo za pretirano optimistično.

S tem, ko smo jo označili za pretirano optimistično, je nikakor nismo razglasili za utopično. Vsekakor lahko rečemo, da je optimizem Fjodorova glede človekove vloge Božjega sodelavca do neke mere upravičen, kar smo se trudili v tej razpravi tudi pokazati. Izkazalo se je, da ne le, da nam Sveto pismo in katoliško cerkveno učiteljstvo nalagata dolžnost oz. odgovornost do stvarstva, da zanj skrbimo in ga branimo pred uničenjem, temveč, da je teološka ideja človeka kot oskrbnika Božjega stvarstva z razumskega in izkustvenega vidika popolnoma sprejemljiva. Še več - celo koristna. Človeštvo namreč potrebuje sanje, ki ga ženejo naprej. Ideja napredka je v človeško družbo vnesla velik optimizem. Če človeštvo ob odkritju temačne usode vesolja noče zapasti v eksistencialno krizo, mora gojiti upanje, da bomo ljudje nekoč morda lahko katastrofo uničenja preprečili.

Seveda se je pri tem treba zavedati, da je najbolj pomembna izjava, ki jo je treba gojiti tako v znanosti kakor tudi v veri: «Ne vem!« Ta preprost kratek stavek nas 
pomaga obvarovati pred utopičnim idealizmom, ki je lahko zelo nevaren. $V$ tej razpravi zagovarjamo srednjo pot med obupom in utopičnim idealizmom, kajti oba imata uničujoče posledice, kar številni zgodovinski dogodki tudi dokazujejo. Človeštvu je treba po eni strani pustiti, da sanja o svetli prihodnosti, po drugi strani pa je treba tudi brzdati pretiran optimizem, v katerega lahko hitro zapade. Najbolj nazoren primer za to je zagotovo komunizem. Katoliška Cerkev zavrača tako komunizem kot tudi njegovo antitezo v obliki liberalnega kapitalizma, ki se vse premalo ozira na dobrobit posameznika, in zagovarja srednjo pot - to je socialno državo.

Enak pristop predlagamo tudi za transhumanizem, ki predstavlja rdečo nit te razprave. Vizija transhumanizma pri Fjodorovu, v kateri napredek človeku omogoča neslutene zmožnosti upravljanja vesolja, nam sicer daje upanje na srečno prihodnost. Vendar moramo to idejo prizemljiti, saj bomo sicer prej ko slej razočarani. Komunizem je s svojo teorijo idealne družbe razočaral mnoge. Prepričani smo, da je glavna naloga katoliške teologije, da prepreči, da bi nas razočaral še transhumanizem. Ta torej nikakor ne sme postati ideologija, ampak mora ostati v mejah zmernega optimizma. To pa je še vedno dovolj, da ohranimo njegov eksistencialni pomen za človeštvo. Ne samo, da nas motivira pri prizadevanju za boljši svet, ampak nas med seboj tudi povezuje. Fjodorov je bil prepričan, da se mora človeštvo združiti v skupni stvari obujanja mrtvih in upravljanja vesolja, ki naj bi ju omogočila znanost. Čeprav so njegovi trashumanistični cilji do neke mere utopični, pa nam sodobna mednarodna prizadevanja za preprečitev ekoloških katastrof - na primer vse bolj očitnih posledic globalnega segrevanja -, ki so skupen projekt sicer razdrobljenih in sprtih držav, kažejo, da je imel Fjodorov v nečem prav: ljudje potrebujemo vsaj kakšen skupni projekt - in iskanje načina za odgovorno upravljanje s stvarstvom (ki vključuje tudi zaščito pred katastrofami), ki ga spodbuja sodobni transhumanizem, danes postaja nekaj konkretnega, kar lahko vsak dan zasledimo tudi v medijih.

Smisel transhumanizma je torej v tem, da ostane v službi odgovornega ravnanja s stvarstvom. Paziti moramo le, da bo ostal v duhu zmernega optimizma. In če nas je strah, da bo človek pri tej odgovorni in zahtevni nalogi naredil kakšno veliko neumnost, si prikličimo v spomin, da se nič na tem svetu ne zgodi brez Božje previdnosti.

\section{Kratice}

CA - Janez Pavel II. 1991. Ob stoletnici [Centesimus Annus].

CV - Benedikt XVI. 2009. Ljubezen v resnici [Caritas in veritate].

FR - Janez Pavel II. 1999. Vera in razum [Fides et ratio].

LE - Janez Pavel II. 1981. O človeškem delu [Laborem exercens].

PP - Pavel VI. 1967. O delu za razvoj narodov [Populorum progressio]. 


\section{Reference}

Benedikt XVI. 2007. World Day of Peace. 1. januar. http://w2.vatican.va/content/benedict-xvi/en/ messages/peace/documents/hf_ben-xvi_ mes_20061208_xl-world-day-peace.html (pridobljeno 5. 9. 2019).

- - 2010. Address to Diplomatic Corps. 11 januar. http://w2.vatican.va/content/benedictxvi/en/speeches/2010/january/documents/ hf_ben-xvi_spe_20100111_diplomatic-corps. html (pridobljeno 5. 9. 2019).

Clay, Eugene. 2005. Transhumanism and the Orthodox Christian Tradition. V: Hava TiroshSamuelson in Kenneth L. Mossman, ur. Building Better Humans?: Refocusing the Debate on Transhumanism, 15 -180. Oxford: Peter Lang.

Coyne, Jerry A. 2018. Verjeti ali vedeti: Zakaj sta znanost in religija nezdružljivi. Prev. Sandi Kodrič. Ljubljana: UMco.

Founders Online. 2019. From Benjamin Franklin to Joseph Banks. National Archives. https:// founders.archives.gov/documents/Franklin/01-40-02-0236 (pridobljeno 5. 9. 2019).

Frančišek. 2013. Audience with Representatives of the Churches and Ecclesial Communities and of the Different Religions. 20. marec. http:// w2.vatican.va/content/francesco/en/speeches/2013/march/documents/papa-francesco_20130320_delegati-fraterni.html (pridobljeno 5. 9. 2019).

Fukuyama, Francis. 2004. Transhumanism: Symposium on the World's Most Dangerous Ideas. Foreign Policy, Sept./Oct. https://foreignpolicy. com/2009/10/23/transhumanism/ (pridobljeno 5. 9. 2019).

Glanz, James. 2009. Astronomy and Cosmology: Big Bang Theory and Modern Cosmology. Encyclopedia.com. https://www.encyclopedia. com/science/science-magazines/astronomy-and-cosmology-big-bang-theory-and-modern-cosmology (pridobljeno 5.9.2019).
Lewis, C. S. 1970. Answers to Questions on Christianity. V: God in the Dock. Grand Rapids: William B. Eerdmans Publishing Company.

McGrath, Alister. 2003. A Scientific Theology. Zv. 3, Theory. Grand Rapids, Michigan: William B. Eerdmans Publishing Company.

- - - 2014. Vodnik po krščanski teologiji. Zv. 1. Prev. Aleš Maver. Celje: Celjska Mohorjeva družba.

Papeški svet Pravičnost in mir. 2007. Kompendij družbenega nauka Cerkve. Ljubljana: Družina.

Porter, Allen. 2017. Bioethics and Transhumanism. The Journal of Medicine and Philosophy 42, št. 3:237-260.

The Columbia River Watershed: Caring for Creation and the Common Good. 2001. An International Pastoral Letter by the Catholic Bishops of the Region. https://wacatholics.org/_ui/ img/files/colrvr-e.pdf (pridobljeno 5. 9. 2019).

The United States Catholic Conference. 1991. Renewing the Earth: An Invitation to Reflection and Action on Environment in Light of Catholic Social Teaching. A Pastoral Statement. 14. november. http://www.usccb.org/issues-andaction/human-life-and-dignity/environment/ renewing-the-earth.cfm (pridobljeno 5. 9. 2019).

The United States Conference of Catholic Bishops. 2001. Global Climate Change: A Plea for Dialogue Prudence and the Common Good. A Statement. 15. junij. http://www.usccb.org/ issues-and-action/human-life-and-dignity/ environment/global-climate-change-a-pleafor-dialogue-prudence-and-the-commongood.cfm (pridobljeno 5. 9. 2019) 